\title{
Presentation Patterns, Diagnostic Modalities, Management Strategies, and Clinical Outcomes in Patients with Hydatid Disease of the Pelvic Bone: A Comparative Review of 31 Cases
}

Faisal Inayat, Shoaib Azam, Areeba S. Baig, Gul Nawaz, Waqas Ullah

1.

Corresponding author: Shoaib Azam, shoiab_738@hotmail.com

\section{Abstract}

Hydatid disease is a parasitic zoonosis commonly caused by Echinococcus granulosus. It characteristically involves the liver and the lungs but rare occurrences in other organs have also been reported. Bone involvement is distinctly uncommon, which is predominantly a silent and slowly progressive disease with a long latent period. We conducted a systematic literature search of MEDLINE, Cochrane, Embase, and Scopus databases. After a comprehensive review of the search results, a total of 31 cases of hydatid disease of the pelvic bone fulfilled the inclusion criteria. The data on patient demographics, epidemiology, lesion site, management, clinical outcomes, and follow-up were collected and analyzed. This review illustrates that hydatid disease should be considered among the differential diagnoses of unusual cystic lesions of the pelvic bone. Prompt diagnosis and appropriate management are of paramount importance to prevent bone destruction and serious complications in these patients. Long-term follow-up should be performed for potential recurrence.

Categories: Internal Medicine, Orthopedics, Public Health

Keywords: hydatid disease, pelvic bone, epidemiology, clinical presentation, lesion site, diagnosis, management, clinical outcomes

\section{Introduction And Background}

Human hydatid disease, also known as cystic echinococcosis, is most commonly caused by Echinococcus granulosus. The lesions of this infectious etiology can be encountered in myriad body locations. While it frequently involves the liver and the lungs, bone involvement is exceedingly rare [1, 2]. Although the incidence of bone disease is remarkably low, its diagnosis and management can be challenging. The clinical presentation of patients with osseous hydatid disease is frequently nonspecific. Occasionally, pain and pathological fractures are the presenting symptoms [3, 4]. In regard to the diagnosis, the findings of clinical history, laboratory studies, radiologic investigations, and histopathologic analysis play a key role [5, 6]. Surgical resection of the cystic lesions with antihelminthic chemotherapy is the treatment of choice. Bone curettage, achieving the negative resection margins, is essentially important to avoid the recurrence of the disease [7]. The prognosis is usually favorable but early treatment may save the patients from inadvertent events as well as excessive surgical debridement requiring bone replacement [8]. The aim of this comparative review was to summarize the data on clinical presentations, diagnostic strategies, management options, and the clinical outcomes in patients with pelvic bone hydatidosis. This paper emphasizes that the clinicians 


\section{Cureus}

should be vigilant for this disease, particularly in patients presenting with nonspecific skeletal symptoms.

\section{Review}

\section{Materials and methods}

We conducted a systematic literature search to retrieve published data on pelvic bone hydatidosis using the MEDLINE, Cochrane, Embase, and Scopus databases. Several controlled vocabulary search terms (medical subject headings [MeSH] and Embase subject headings [Emtree]), terminologies like "hydatid disease," "bone," "pelvis," “pelvic involvement," and "management" were combined using the Boolean operators "AND" and "OR" with the terms "hydatidosis," "outcome," and "chemotherapy." The search was conducted without a defined time filter, with language limitation to English-only articles. Additionally, a manual search was also performed using the bibliography of all accessed publications through the abovementioned search strategy. We initially screened all retrieved titles and abstracts to determine their relevance to our topic. The same protocol was used to screen the selected articles for full texts to check their relevance.

\section{Results}

A total of 127 studies were initially obtained, consisting of but not limited to original articles, case series, and case reports. After excluding 49 duplicate articles, 78 papers were thoroughly studied. The articles available in any language other than the English were excluded from the review. Thirty-two papers were found relevant to the scope of our study but 15 studies were found accessible in order to retrieve pertinent data required for this review [9-23]. The total number of patients in this comparative review was 31 as some case studies consisted of more than one patients. The data on individual cases of pelvic bone hydatidosis on patient demographics, locations of the lesions, management, and clinical outcomes are summarized (Table 1).

\begin{tabular}{|c|c|c|c|c|c|c|}
\hline Authors & $\begin{array}{l}\text { Publication } \\
\text { year }\end{array}$ & Country & Age/gender & Lesion site & Management & Outcome \\
\hline $\begin{array}{l}\text { Agarwal et } \\
\text { al. [9] }\end{array}$ & 1991 & KSA & 70/F & $\begin{array}{l}\text { Ilium and } \\
\text { sacroiliac joint }\end{array}$ & $\begin{array}{l}\text { Surgical excision and } \\
\text { chemotherapy }\end{array}$ & $\begin{array}{l}\text { Symptom-free in 18- } \\
\text { month follow-up }\end{array}$ \\
\hline $\begin{array}{l}\text { Agarwal et } \\
\text { al. [9] }\end{array}$ & 1991 & KSA & $43 / F$ & $\begin{array}{l}\text { Pubis, ischium, } \\
\text { acetabulum, and } \\
\text { proximal femur }\end{array}$ & $\begin{array}{l}\text { Surgical excision and } \\
\text { chemotherapy }\end{array}$ & $\begin{array}{l}\text { Symptom-free in four- } \\
\text { year follow-up }\end{array}$ \\
\hline $\begin{array}{l}\text { Wirbel et } \\
\text { al. [10] }\end{array}$ & 1995 & Yugoslavia & 49/M & $\begin{array}{l}\text { Ilium, pubis, } \\
\text { acetabulum, and } \\
\text { proximal femur }\end{array}$ & $\begin{array}{l}\text { Chemotherapy for five } \\
\text { years followed by partial } \\
\text { pelvic resection and } \\
\text { prosthetic replacement }\end{array}$ & $\begin{array}{l}\text { Recurrence was treated } \\
\text { with custom-made } \\
\text { prosthesis }\end{array}$ \\
\hline $\begin{array}{l}\text { Belzunegui } \\
\text { et al. [11] }\end{array}$ & 1997 & Spain & $54 / F$ & $\begin{array}{l}\text { Hemipelvis and } \\
\text { proximal femur }\end{array}$ & $\begin{array}{l}\text { Girdlestone arthroplasty } \\
\text { and chemotherapy }\end{array}$ & $\begin{array}{l}\text { Recurrence was } \\
\text { managed with } \\
\text { chemotherapy }\end{array}$ \\
\hline $\begin{array}{l}\text { Martinez et } \\
\text { al. [12] }\end{array}$ & 2001 & Spain & 56/M & $\begin{array}{l}\text { llium and sacral } \\
\text { ala }\end{array}$ & $\begin{array}{l}\text { One surgical drainage and } \\
\text { chemotherapy }\end{array}$ & $\begin{array}{l}\text { Symptom-free in three- } \\
\text { year follow-up }\end{array}$ \\
\hline Martinez et & 2001 & Spain & $62 / F$ & Ilium & Two surgical drainages & Symptom-free in six-year \\
\hline
\end{tabular}




\section{Cureus}

al. [12]

Martinez et
al. [12]

2001

Martinez et

al. [12]

Martinez et

al. [12]

2001

Martinez et

al. [12]

2001

Martinez et

al. [12]

Martinez et

al. [12]

2001

Spain

74/M

Masse et

al. [13]

2004

Khan et al.

[14]

2008

Nepa

41/M

Superior pubic

ramus and body

\section{Femur}

Siwach et $2009 \quad$ India 51/F

al. [15]

Nath et al.

[16]

2009

India

$35 / \mathrm{M}$

Winning et

al. [17]

2009

Australia

$77 / \mathrm{F}$

Neelapala

et al. [18]

2010

UK

35/F

Notarnicola

et al. [19]
2010

Italy

53/F fracture) and pelvis

Ilium,

acetabulum, and pubic rami

Left femur, hemipelvis, and adjacent soft tissues ileum

Proximal femur and chemotherapy

follow-up

One surgical drainage and chemotherapy

Symptom-free in fouryear follow-up

One surgical drainage and chemotherapy

Symptom-free during five-year follow-up

Symptom-free in sevenyear follow-up

Non-functioning limb, productive sinuses, hip pain, walking difficulty in 13 years of follow-up

Non-functioning limb,

Numerous surgical

drainages and

chemotherapy

productive sinuses, hip pain, walking difficulty in nine-year follow-up

Non-functioning limb, hip pain, walking difficulty in 12-year follow-up

Symptom-free during 12 years of follow-up

Symptomatic improvement after three months

Death due to sepsis ischial tuberosity,

Wide excision

Not reported

Femoral head excision and chemotherapy

Septic shock likely from secondary bacterial infection of the hip sinus

Chemotherapy for two

Hip joint and years followed by cemented total hip replacement customized hemipelvic replacement (pathological Total hip replacement fracture)
Recurrent dislocation and disassembly; revised with Wagner-type prosthesis 


\section{Cureus}

\begin{tabular}{|c|c|c|c|c|c|c|}
\hline $\begin{array}{l}\text { Liang et al. } \\
\text { [20] }\end{array}$ & 2014 & China & 29/M & $\begin{array}{l}\text { pubis, hip, and } \\
\text { greater } \\
\text { trochanter }\end{array}$ & $\begin{array}{l}\text { hemipelvis replantation } \\
\text { with femoral prosthesis } \\
\text { replacement, and } \\
\text { chemotherapy }\end{array}$ & $\begin{array}{l}\text { Symptom-free in seven } \\
\text { years of follow-up }\end{array}$ \\
\hline $\begin{array}{l}\text { Liang et al. } \\
\text { [20] }\end{array}$ & 2014 & China & 26/F & Ilium & $\begin{array}{l}\text { Four debridements and } \\
\text { chemotherapy }\end{array}$ & $\begin{array}{l}\text { Symptom-free in nine } \\
\text { years of follow-up }\end{array}$ \\
\hline $\begin{array}{l}\text { Liang et al. } \\
\text { [20] }\end{array}$ & 2014 & China & $24 / F$ & $\begin{array}{l}\text { Ilium and } \\
\text { acetabulum }\end{array}$ & $\begin{array}{l}\text { Two debridements, bone } \\
\text { cement filling, and } \\
\text { chemotherapy }\end{array}$ & $\begin{array}{l}\text { Symptom-free in five- } \\
\text { year follow-up }\end{array}$ \\
\hline $\begin{array}{l}\text { Liang et al. } \\
\text { [20] }\end{array}$ & 2014 & China & $45 / F$ & Acetabulum & $\begin{array}{l}\text { Internal fixation with bone } \\
\text { cement filling }\end{array}$ & $\begin{array}{l}\text { Symptom-free during two } \\
\text { years of follow-up }\end{array}$ \\
\hline $\begin{array}{l}\text { Liang et al. } \\
\text { [20] }\end{array}$ & 2014 & China & $31 / \mathrm{M}$ & Ilium & $\begin{array}{l}\text { Two debridements with } \\
\text { radiotherapy and } \\
\text { chemotherapy }\end{array}$ & $\begin{array}{l}\text { Symptom-free in six } \\
\text { years of follow-up }\end{array}$ \\
\hline $\begin{array}{l}\text { Liang et al. } \\
\text { [20] }\end{array}$ & 2014 & China & $52 / \mathrm{M}$ & Ilium & Numerous debridements & $\begin{array}{l}\text { Hip pain during seven } \\
\text { years of follow-up }\end{array}$ \\
\hline $\begin{array}{l}\text { Liang et al. } \\
\text { [20] }\end{array}$ & 2014 & China & $14 / \mathrm{F}$ & Ilium and sacrum & $\begin{array}{l}\text { Numerous debridements, } \\
\text { one screw and rod fixation, } \\
\text { and chemotherapy }\end{array}$ & $\begin{array}{l}\text { Walking difficulty, } \\
\text { productive sinuses } \\
\text { during } 19 \text { years of follow- } \\
\text { up }\end{array}$ \\
\hline $\begin{array}{l}\text { Liang et al. } \\
\text { [20] }\end{array}$ & 2014 & China & $35 / F$ & $\begin{array}{l}\text { Ilium and } \\
\text { acetabulum }\end{array}$ & $\begin{array}{l}\text { Five debridements and } \\
\text { chemotherapy }\end{array}$ & $\begin{array}{l}\text { Hip pain during seven } \\
\text { years of follow-up }\end{array}$ \\
\hline $\begin{array}{l}\text { Liang et al. } \\
\text { [20] }\end{array}$ & 2014 & China & $32 / F$ & $\begin{array}{l}\text { Ilium and } \\
\text { sacroiliac joint }\end{array}$ & $\begin{array}{l}\text { Three debridements with } \\
\text { radiotherapy, and } \\
\text { chemotherapy }\end{array}$ & $\begin{array}{l}\text { Walking difficulty in four } \\
\text { years of follow-up }\end{array}$ \\
\hline $\begin{array}{l}\text { Raj and } \\
\text { Dash [21] }\end{array}$ & 2015 & India & 40/M & $\begin{array}{l}\text { llium, ischium, } \\
\text { pubis, sacrum, } \\
\text { hip joint, and } \\
\text { head and neck of } \\
\text { femur }\end{array}$ & $\begin{array}{l}\text { Wide local excision, } \\
\text { curettage, internal fixation } \\
\text { of the right femur and } \\
\text { chemotherapy }\end{array}$ & $\begin{array}{l}\text { Disease-free and } \\
\text { ambulant with crutches }\end{array}$ \\
\hline $\begin{array}{l}\text { Tsagozis } \\
\text { and Brosjo } \\
{[22]}\end{array}$ & 2015 & Turkey & 56/M & $\begin{array}{l}\text { Hemipelvis, } \\
\text { sacrum, femur }\end{array}$ & Extended hemipelvectomy & $\begin{array}{l}\text { Symptom-free at one- } \\
\text { year follow-up }\end{array}$ \\
\hline $\begin{array}{l}\text { natnagar } \\
\text { al. [23] }\end{array}$ & 2017 & India & $35 / F$ & $\begin{array}{l}\text { Femoral head } \\
\text { and acetabulum }\end{array}$ & $\begin{array}{l}\text { Surgical debridement and } \\
\text { chemotherapy }\end{array}$ & $\begin{array}{l}\text { Disease-free after three } \\
\text { months }\end{array}$ \\
\hline
\end{tabular}

\section{TABLE 1: The Demographic, Lesion Site, Treatment, and Outcome Data of Patients with Pelvic Bone Hydatidosis.}


male, $\mathrm{n}=14$ ). The mean age of patients was 47 years (range: $14-77$ years). According to our analysis, ilium $(n=21)$ was the most frequent lesion site followed by acetabulum $(n=7)$, pubis $(n=6)$, ischium $(n=5)$ and sacrum $(n=5)$. In a few patients, concurrent involvement of the long bones like femur and/or soft-tissue structures of the pelvis was also noticed.

\section{Epidemiology}

According to one estimate, the incidence of bone involvement has been described to range from $0.5 \%$ to $4 \%$ of all cases of hydatidosis [24]. The bone disease predominantly involves the spine, which is encountered in approximately $50 \%$ to $60 \%$ of the cases, followed by the femur, tibia, humerus, skull, and ribs. With regard to geographical distribution, hydatid disease is globally distributed, especially in the north and northwestern China, parts of South America, East Africa, Australia, Central Asia, North Africa, Russia, Western Europe, and southern United States [24]. The highest prevalence is noted in rural areas where animals are slaughtered. In the recent past, several hydatid elimination programmes had been implemented, with varying degrees of success. Recently, hydatid vaccine has also been considered to combat this crippling infestation.

\section{Pathogenesis}

Although the bone is an uncommon location for hematogenous dissemination of hydatid disease, the presence of the lesions has frequently been reported. The progression of the disease takes place either due to the formation of diverticula or exogenous vesiculation. This disease ensues destructive pathological osseous sequels predominantly by three mechanisms: a) the cyst that increases in size gradually compresses the adjacent tissues, eventually causing compression-related bone atrophy, b) occasionally, the hydatid cyst may obstruct the vessels entering the bones through nutrient foramina causing ischemia, c) the cells like osteoclasts, proliferate around the infectious focus of hydatidosis. On the contrary, the extraosseous invasion culminates in the bone disruption that subsequently may lead to pathologic fracture of the involved portions of the bone [24].

\section{Clinical presentation}

The clinical presentation of bone hydatidosis is frequently varied. It is notable that the bone involvement is largely a silent disorder that has the propensity to remain dormant for decades. Pain, swelling, walking abnormalities, sinus tract formation, ambiguous abdominal pain, or compressive manifestations are among the symptoms and signs of this disease. In patients with hydatidosis of pelvis involving the lumbosacral neural plexus, sciatica becomes the first clinical symptom. Similarly, a vast majority of patients initially present with late complications of this disease like a pathologic fracture, neurological deficits, infected cyst or fistula formation [24]. The physical examination is mostly inconclusive for abnormalities. However, in rare instances, changes in the limb symmetry, abscess or fistula formation or vertebral deformation can be deciphered. Individuals like sheepherders, veterinarians, or butchers are particularly prone to this infection. Therefore, this disease warrants awareness and updated knowledge on part of clinicians, especially in endemic areas when patients present with generalized musculoskeletal complaints.

\section{Diagnosis}

The diagnosis of pelvic bone hydatidosis frequently poses a challenge as pelvic localization by radiological modalities may be difficult and clinical features are mostly nonspecific. Although serological testing has gained importance recently, their sensitivity and specificity is not 100\% [25]. Computed tomography is an excellent modality to detect osseous hydatidosis. The radiologic investigations often demonstrate multiple expanding lesions with no defined margins. The lesions may assume a classic waffle appearance due to extensive osteolysis [26]. 
The unique pathogenetic changes encountered in this disease lead to weakening of the cortical bone, without any periosteal reaction. Magnetic resonance imaging has also been used to investigate the regional disease extent, especially soft-tissue involvement. The hydatid lesions appear as a hyposignal in T1-weighted images and a hypersignal in T2-weighted images [27]. In these patients, a whole-body scan is performed in order to assess the concurrent involvement of other organ systems. As the diagnostic dilemma is frequently noted, tuberculosis, malignancy, aneurysms, and metastatic lesions should be excluded based on the standard set of investigations [27]. A definitive diagnosis is established on the basis of histopathologic examination of the biopsy and/or resected specimen.

\section{Management}

In terms of management, hydatid disease of the pelvic bone is particularly a serious clinicopathologic entity as the cyst in this location may invade pelvic joints, which can potentially make complete recovery difficult. Although the definitive treatment of bony hydatidosis is surgery, a number of studies have highlighted the combination of antihelminthic chemotherapy and surgery as a feasible choice [28]. In the published medical literature, several surgical methods, including simple drainage or debridement, complete excision, total hip arthroplasty, bone grafting, femoropubic arthrodesis, megaprosthetic replacement, massive arthroplasty, osteosynthesis, and hemipelvectomy have been reported thus far [29].

The procedure of simple drainage or debridement is commonly employed; however, early recurrence and inadvertent disease dissemination may occur due to incomplete removal. In this technique, the lesion is exposed while adjoining normal structures are protected with the use of $20 \% \mathrm{NaCl}$ solution. The burnishing of the inner walls of the lesion cavity is also important to avoid recurrence of the disease. This method is mostly used in patients where cystic echinococcosis cannot be excluded preoperatively [29]. Furthermore, bone cement filling is a reliable option to avoid the relapse of the cystic lesions due to its ability to kill the daughter cysts due to necrotizing effects of increased temperature in the polymerizing cement [30]. Several surgical methods are used for reconstruction of osseous portions affected by the hydatidosis. A pedicle screw-rod system is an effective reconstructive option with no need for extensive preoperative feasibility assessment but it may present a dilemma while treating joint involvement. Partial excision of the cystic lesions followed by joint arthroplasty is a good method in this regard [18]. Similarly, megaprosthetic replacement may also help to restore acceptable limb functionality [10]. The major goal of these procedures is to restore the limb function rather than complete eradication of the infectious etiology due to echinococcosis. The use of liquid nitrogen carries several benefits; however, its role in disinfection of bony Echinococcus cysts has rarely been documented. However, Liang et al. supported the notion that bony cystic lesions due to E. granulosus maybe enervated by utilizing liquid nitrogen for a time period of 20 minutes [20].

The therapeutic strategy for hydatid disease with bone involvement resembles oncologic therapy compared to the surgical treatment of visceral hydatidosis [24]. In these patients, a combination of preoperative antihelminthic chemotherapy, surgery, and postoperative antihelminthic chemotherapy demonstrates promising outcomes. Before surgical intervention, medical therapy, mostly consisting of albendazole, targets the cyst size reduction and limits the infectious process. In the post-operative setting, it is primarily used for the treatment of potentially undetectable cysts, ultimately avoiding the recurrence. Similarly, irradiation can be used in patients who cannot tolerate the chemotherapy and/or in inoperable disease [31].

\section{Prognosis}

The prognosis of hydatid disease of the pelvic bone largely depends on its bony extensions. In cases with a widespread disease demonstrating an involvement of the pelvic joints and long 
bones, the prognosis is generally poor. These patients are particularly prone to life-threatening sepsis. Furthermore, if the disease involves several muscle groups or muscle layers, the prognosis is not good and it poses a significant therapeutic challenge due to the presence of sinus and/or fistula formation [32]. In the light of these observations, early diagnosis of pelvic bone hydatidosis is critically important as a late detection makes it a difficult-to-treat disease [33].

\section{Conclusions}

Although pelvic bone hydatidosis is rare, a high index of clinical suspicion should be maintained for this disease, especially in endemic areas. These patients may pose a diagnostic challenge due to nonspecific clinical presentation. The radiological characteristics of the hydatid cyst often suggest the pathology but a definitive diagnosis can only be made by histopathologic examination. Early diagnosis is of paramount importance for the bone salvage and to avoid complications. The treatment of choice is a combination of chemotherapy and surgical debridement. Meticulous technical preparation is necessary as surgery of the pelvis is relatively difficult and incomplete resection of the cyst may culminate in recurrence. The present paper highlights the importance of early detection of the pelvic bone hydatidosis followed by efficient management for a good clinical outcome.

\section{Additional Information}

\section{Disclosures}

Conflicts of interest: In compliance with the ICMJE uniform disclosure form, all authors declare the following: Payment/services info: All authors have declared that no financial support was received from any organization for the submitted work. Financial relationships: All authors have declared that they have no financial relationships at present or within the previous three years with any organizations that might have an interest in the submitted work. Other relationships: All authors have declared that there are no other relationships or activities that could appear to have influenced the submitted work.

\section{References}

1. Kapoor SK, Kataria H, Patra SR, Bharadwaj M, Vijay V, Kapoor S: Multi-organ hydatidosis with extensive involvement of the hemi-pelvis and ipsilateral femur. Parasitol Int. 2013, 62:82-85. 10.1016/j.parint.2012.08.006

2. Gnanasekaran KK, Prabhu AJ, George S: Osseous hydatidosis of femur in a patient with fracture non-union: an uncommon entity. J Clin Diagn Res. 2016, 10:ED06-ED08. 10.7860/JCDR/2016/23610.9097

3. Salman F, Khan MI, Hussain I, Abdullah HMA: Pathological fracture of femoral neck in a middle-aged woman: a rare presentation of primary hydatid cyst disease in humans. BMJ Case Rep. 2018, 2018:bcr-2017-222980. 10.1136/bcr-2017-222980

4. Monge-Maillo B, Chamorro Tojeiro S, Lopez-Velez R: Management of osseous cystic echinococcosis. Expert Rev Anti Infect Ther. 2017, 15:1075-1082. 10.1080/14787210.2017.1401466

5. Zarzosa MP, Orduña Domingo A, Gutierrez P, et al.: Evaluation of six serological tests in diagnosis and postoperative control of pulmonary hydatid disease patients. Diagn Microbiol Infect Dis. 1999, 35:255-262. 10.1016/S0732-8893(99)00079-6

6. Biava MF, Dao A, Fortier B: Laboratory diagnosis of cystic hydatic disease. World J Surg. 2001, 25:10-14. 10.1007/s002680020002

7. Eckert J, Thompson RC: Historical aspects of echinococcosis. Adv Parasitol. 2017, 95:1-64. 10.1016/bs.apar.2016.07.003

8. Ertem M, Karahasanoglu T, Yavuz N, Erguney S: Laparoscopically treated liver hydatid cysts. Arch Surg. 2002, 137:1170-1173. 10.1001/archsurg.137.10.1170

9. Agarwal S, Shah A, Kadhi SK, Rooney RJ: Hydatid bone disease of the pelvis. A report of two 
cases and review of the literature. Clin Orthop Relat Res. 1992, 280:251-255.

10. Wirbel RJ, Mues PE, Mutschler WE, Salomon-Looijen M: Hydatid disease of the pelvis and the femur: a case report. Acta Orthop Scand. 1995, 66:440-442. 10.3109/17453679508995582

11. Belzunegui J, Maiz O, Lopez L, Plazaola I, Gonzalez C, Figueroa M: Hydatid disease of bone with adjacent joint involvement. A radiological follow-up of 12 years. Br J Rheumatol. 1997, 36:133-135. 10.1093/rheumatology/36.1.133

12. Martinez AA, Herrera A, Cuenca J, Herrero L: Hydatidosis of the pelvis and hip . Int Orthop. 2001, 25:302-304. 10.1007/s002640100278

13. Masse A, Parola PG, Brach del Prever EM, Gallinaro P: Hydatidosis of the pelvis: a case report with a 25-year follow-up. Arch Orthop Trauma Surg. 2004, 124:203-205. 10.1007/s00402-0030624-7

14. Khan JA, Devkota P, Acharya BM, Pradhan NM, Shreshtha S: Bony hydatid disease of superior pubic ramus with extension into pelvis and proximal thigh. JNMA J Nepal Med Assoc. 2008, 47:139-141. 10.31729/jnma.321

15. Siwach R, Singh R, Kadian VK, Singh Z, Jain M, Madan H, Singh S: Extensive hydatidosis of the femur and pelvis with pathological fracture: a case report. Int J Infect Dis. 2009, 13:480482. 10.1016/j.ijid.2008.12.017

16. Nath P, Bhattacharya S, Dutta V, Joshi GR, Patel M: Primary iliac bone hydatid disease: an unusual presentation. Med J Armed Forces India. 2009, 65:180-181. 10.1016/S03771237(09)80141-X

17. Winning A, Braslins P, McCarthy JS: Nitazoxanide for treatment of refractory bony hydatid disease. Am J Trop Med Hyg. 2009, 80:176-178. 10.4269/ajtmh.2009.80.176

18. Neelapala VS, Chandrasekar CR, Grimer RJ: Revision hip replacement for recurrent Hydatid disease of the pelvis: a case report and review of the literature. J Orthop Surg Res. 2010, 5:17. 10.1186/1749-799X-5-17

19. Notarnicola A, Panella A, Moretti L, Solarino G, Moretti B: Hip joint hydatidosis after prosthesis replacement. Int J Infect Dis. 2010, 14:287-290. 10.1016/j.ijid.2009.12.006

20. Liang Q, Wen H, Yunus A, Tian Z, Jiang F, Song X: Treatment experiences of pelvic bone hydatidosis. Int J Infect Dis. 2014, 18:57-61. 10.1016/j.ijid.2013.09.010

21. Raj DH, Dash PK: Hydatid disease of bone: a dangerous crippling disease . BMJ Case Rep. 2015, 2015:bcr2015211697. 10.1136/bcr-2015-211697

22. Tsagozis P, Brosjo O: Giant hydatid cyst of the pelvis, femur and retroperitoneal space: surgical treatment with extended hemipelvectomy. BMJ Case Rep. 2015, 2015:bcr2015209715. 10.1136/bcr-2015-209715

23. Bhatnagar N, Kishan H, Sura S, Lingaiah P, Jaikumar K: Pelvic hydatid disease: a case report and review of literature. J Orthop Case Rep. 2017, 7:25-28. 10.13107/jocr.2250-0685.834

24. Song XH, Ding LW, Wen H: Bone hydatid disease. Postgrad Med J. 2007, 83:536-542. 10.1136/pgmj.2007.057166

25. Zlitni M, Ezzaouia K, Lebib H, Karray M, Kooli M, Mestiri M: Hydatid cyst of bone: diagnosis and treatment. World J Surg. 2001, 25:75-82. 10.1007/s002680020010

26. Torricelli P, Martinelli C, Biagini R, Ruggieri P, De Cristofaro R: Radiographic and computed tomographic findings in hydatid disease of bone. Skeletal Radiol. 1990, 19:435-439. 10.1007/BF00241799

27. Tekkok IH, Benli K: Primary spinal extradural hydatid disease: report of a case with magnetic resonance characteristics and pathological correlation. Neurosurgery. 1993, 33:320-323. 10.1227/00006123-199308000-00023

28. Gautam D, Malhotra R, Dubey S: Combination drug chemotherapy and massive skeletal allograft in the management of hydatid disease of femur. BMJ Case Rep. 2018, 2018:bcr-2017223332. 10.1136/bcr-2017-223332

29. Gdoura F, Trigui M, Zribi W, Ellouze Z, Bouzidi R, Ayedi K, Keskes H: Pelvic bone hydatidosis. J Orthop Traumatol Surg Res. 2010, 96:85-89. 10.1016/j.otsr.2009.04.020

30. Yildiz Y, Bayrakci K, Altay M, Saglik Y: The use of polymethylmethacrylate in the management of hydatid disease of bone. J Bone Joint Surg Br. 2001, 83:1005-1008. 10.1302/0301-620X.83B7.0831005

31. Xie Z, Chen L, Xie Q, Bao Y, Luo X, Yi C, Wen H: Surgery or radiotherapy for the treatment of bone hydatid disease: a retrospective case series. Int J Infect Dis. 2015, 33:114-119. 10.1016/j.ijid.2014.12.037

32. Merkle EM, Schulte M, Vogel J, et al.: Musculoskeletal involvement in cystic echinococcosis: 
Cureus

report of eight cases and review of the literature. AJR Am J Roentgenol. 1997, 168:1531-1534. 10.2214/ajr.168.6.9168719

33. Steinmetz S, Racloz G, Stern R, et al.: Treatment challenges associated with bone echinococcosis. J Antimicrob Chemother. 2014, 69:821-826. 10.1093/jac/dkt429 